\title{
Evaluasi Model Perencanaan Persediaan Obat dengan Pendekatan Simulasi
}

\author{
Eri Wirdianto ${ }^{1}$, Meiyola Syaflinda ${ }^{1}$, Milana ${ }^{2 *}$ \\ ${ }^{1}$ Jurusan Teknik Industri, Fakultas Teknik, Universitas Andalas \\ ${ }^{2}$ Jurusan Teknik Otomotif, Fakultas Teknik, Universitas Negeri Padang \\ *Corresponding author, e-mail: milana@ft.unp.ac.id
}

\begin{abstract}
Abstrak - Permasalahan yang dihadapi apotek saat ini yaitu masalah persediaan obat dimana terdapat beberapa jenis obat yang persediaannya tidak bisa memenuhi kebutuhan konsumen tetapi terkadang mengalami kelebihan stok. Penelitian ini bertujuan untuk menentukan metode terbaik dalam menentukan kuantitas persediaan obat dengan kriteria service level tertinggi dan total cost terendah. Pada pengklasifikasian obat berdasarkan analisis ABC, obat yang dipilih hanya obat yang masuk ke dalam kategori A dan 10 jenis obat termahal. Setelah itu dilakukan perhitungan nilai persediaan dengan menggunakan tiga metode yaitu EOQ, Joint Replenishment, dan Sistem (Q,r). Evaluasi untuk ketiga metode tersebut menggunakan pendekatan simulasi. Model simulasi ini dibangun dengan cara memasukkan pola-pola permintaan untuk masing-masing obat serta memasukkan nilai persediaan untuk masing-masing metode yang telah dihitung sebelumnya. Dari hasil perhitungan dengan pendekatan simulasi untuk masing-masing metode didapatkan perbandingan nilai total cost dan service level. Nilai service level tertinggi dan total cost terendah untuk hasil perhitungan dan hasil simulasi memiliki hasil yang sama yaitu metode Joint Replenishment.
\end{abstract}

Kata Kunci : perencanaan persediaan, apotek, simulasi, stock out, service level

\begin{abstract}
The problem faced by the pharmacy today is the problem of drug supply where there are some drugs that cannot meet the needs of consumers (stock out) but sometimes overstock. This study aims to recommend the best method in determining the quantity of stock of drugs to improve service level at the lowest total cost. The steps taken in solving the problem of drug supply are based on $\mathrm{ABC}$ analysis. The selected drugs are the drugs that fall into category $A$ and the 10 most expensive types of drugs. After that, the inventory value is calculated using three methods, namely EOQ, Joint Replenishment, and System (Q,r). The evaluation is conducted for these three methods using a simulation approach. This simulation model is built by entering the demand patterns for each drug and entering inventory values for each method that has been previously calculated. After that, the best method with the highest service level criteria and the lowest total cost is chosen. The highest service level value and the lowest total cost for the calculation and simulation results showed the same result, which is Joint Replenishment method.
\end{abstract}

Keywords : inventory planning, pharmacy, simulation, stock out, service level

This is an open access article distributed under the Creative Commons 4.0 Attribution License, which permits unrestricted use, distribution, and reproduction in any medium, provided the original work is properly cited. C2019 by Author and Universitas Negeri Padang

\section{Pendahuluan}

Persediaan merupakan suatu sumber daya menganggur yang disediakan untuk memenuhi permintaan dari pelanggan. Tanpa adanya persediaan, suatu usaha akan menghadapi resiko pada waktu tertentu tidak dapat memenuhi keinginan pelanggan yang memerlukan atau meminta barang. Oleh karena itu persediaan menjadi masalah penting yang harus diselesaikan oleh perusahaan. Salah satu upaya dalam mengantisipasi masalah persediaan ini yaitu dengan mengadakan sistem pengendalian pada persediaan. Tujuan utama dari pengendalian persediaan adalah untuk menjaga tingkat persediaan suatu barang pada tingkat optimal dengan resiko sekecil mungkin [1].

Manajemen persediaan yang baik dapat menjadi 
senjata baru bagi perusahaan dalam menghadapi konsumen. Kadang kala lebih dari 50\% produk yang disimpan adalah produk yang jarang sekali permintaannya. Hal ini harus menjadi pertimbangan untuk menentukan jumlah persediaan yang tepat untuk produk-produk tersebut. Apabila hal ini dibiarkan, maka akan merugikan perusahaan karena banyak dana yang tertanam dalam produk tersebut. Pada kenyataannya, menjaga persediaan bukanlah hal yang mudah apalagi melibatkan jumlah item yang banyak. Sangat sulit menyelesaikan persoalan kapan dan berapa item yang harus dibeli. Diperlukan keputusan yang tepat dalam penentuan kebijakan sistem persediaan yang sesuai untuk perusahaan. Salah satu jenis produk yang memiliki banyak jumlah item yaitu obat.

Obat merupakan komponen yang sangat penting dalam upaya pelayanan kesehatan untuk masyarakat. Obat berfungsi sebagai komponen utama dalam penyembuhan penyakit. Ketersediaan dan kualitas obat harus selalu terjaga sebagai salah satu jaminan terhadap kualitas layanan kesehatan yang diberikan kepada pelanggan [2]. Oleh karena itu, persediaan obat harus maksimal dalam memenuhi setiap kebutuhan. Keberadaan obat merupakan kondisi pokok yang harus terjaga ketersediaannya.

Apotek merupakan tempat dimana obat bisa diperjualbelikan kepada konsumen yang membutuhkan. Setiap pasien yang menerima resep obat dari dokter akan mengambil atau membeli obat sesuai dengan resep dokter tersebut di apotek yang ada di rumah sakit tempat dia berobat. Apotek akan selalu memerlukan persediaan obat untuk memenuhi kebutuhan pelanggan. Selain itu, tujuan persediaan obat adalah untuk menjaga pelayanan obat di apotek tetap berjalan dengan baik.

Penelitian terhadap sistem persediaan obat ini bertujuan untuk menentukan kebijakan persediaan (jumlah pemesanan optimal, titik pemesanan kembali, interval waktu pemesanan), serta menghitung nilai total cost dan service level dari obat-obat yang digunakan. Pendekatan yang dilakukan menggunakan tiga metode yaitu Economic Order Quantity (EOQ), Joint Replenishment, dan Sistem (Q,r) serta mengevaluasi ketiga metode perencanaan persediaan dengan pendekatan simulasi untuk memilih metode terbaik dengan kriteria nilai service level tertinggi dan total cost terendah.

\section{MetOdE}

\section{A. Pemilihan Metode}

Metode EOQ merupakan model persediaan sederhana yang bertujuan untuk menentukan ukuran pemesanan yang paling ekonomis yang dapat meminimasi biaya-biaya dalam persediaan $[3,4]$. Sementara itu, Joint Replenishment merupakan metode pemesanan beberapa item secara simultan sehingga dapat mengurangi biaya pemesanan [5]. Sedangkan pada Sistem (Q,r), pemesanan kembali dilakukan apabila posisi persediaan sudah sama dengan atau lebih kecil dari titik pemesanan kembali [6]. Pada metode ini, kuantitas pemesanan selalu tetap sedangkan jarak waktu pemesanan akan berubah-ubah sesuai posisi persediaan.

Ketiga metode perencanaan persediaan ini dipilih berdasarkan metode persediaan yang ada yaitu metode persediaan deterministik dan probabilistik. Untuk model persediaan deterministik digunakan metode EOQ dimana metode EOQ ini merupakan metode perencanaan persediaan yang umum dan sering digunakan. Selanjutnya untuk perencanaan persediaan probabilistik, metode yang digunakan adalah Joint Replenishment. Metode ini menggabungkan pemesanan produk sehingga dapat menghemat biaya pemesanan. Sedangkan untuk sistem Q digunakan metode $(\mathrm{Q}, \mathrm{r})$. Metode $(\mathrm{Q}, \mathrm{r})$ digunakan karena banyak dipakai pada permasalahan stokastik. Hal ini disebabkan pada sistem (Q,r) dilakukan pemeriksaan secara terus menerus sehingga dapat meminimalkan kemungkinan untuk terjadinya stockout. Setelah dilakukan perhitungan dengan menggunakan ketiga metode di atas, maka dilakukan evaluasi untuk ketiga metode tersebut dengan pendekatan simulasi.

\section{B. Tahapan Penelitian}

Tahapan penelitian evaluasi model perencanaan persediaan obat yaitu sebagai berikut:

1. Tahap survei pendahuluan dan studi literatur Survei pendahuluan dilakukan dengan melakukan survei sistem di apotek Rumah Sakit $X$. Survei ini terdiri dari observasi sistem dan wawancara dengan apoteker. Survei sistem dilakukan untuk mendapatkan gambaran dan informasi mengenai sistem persediaan obat di apotek Rumah Sakit X. Studi literatur dilakukan untuk mendapatkan referensi-referensi yang dapat dijadikan sebagai pedoman dalam menyelesaikan penelitian ini.

2. Identifikasi masalah 
Permasalahan yang dibahas dalam penelitian ini adalah bagaimana cara menentukan metode terbaik dalam menentukan kuantitas persediaan obat dengan kriteria meningkatkan service level dan total cost terendah.

3. Perancangan model simulasi

Tahapan perancangan model simulasi terdiri dari:

a. Penentuan parameter model

Data untuk parameter yang digunakan dalam pembuatan model simulasi terdiri dari: kuantitas permintaan obat, waktu antar kedatangan permintaan obat, kuantitas persediaan obat, kuantitas pemesanan optimal masing-masing metode, kuantitas Reorder Point (ROP) masing-masing metode, dan leadtime pengiriman obat oleh supplier.

b. Analisis data input

Data input yang digunakan dalam model simulasi yaitu tingkat kedatangan permintaan dan waktu antar kedatangan permintaan obat. Distribusi yang digunakan untuk kedua data tersebut yaitu distribusi diskrit. Hal ini dikarenakan interval waktu yang digunakan pada sistem yaitu besifat diskrit.

c. Verifikasi model simulasi

Proses verifikasi dilakukan dengan debugging terhadap program simulasi yang telah dibuat untuk mendeteksi kesalahankesalahan yang terdapat dalam konfigurasi program. Verifikasi juga dilakukan dengan uji coba input nilai konstan terhadap distribusi yang digunakan dan dengan melihat animasi pada model simulasi.

d. Validasi model simulasi

Metode yang digunakan untuk validasi terdiri dari black box validation dan white box validation. Black box validation dilakukan dengan membandingkan output model dengan data aktual sedangkan white box validation dengan memperhatikan struktur internal dari model tersebut terhadap struktur sistem yang sebenarnya.

4. Hasil dan pembahasan

Pada tahap ini dilakukan analisis dan pembahasan mengenai hasil perhitungan dan hasil evaluasi dengan Arena ${ }^{\circledR}$.
5. Kesimpulan dan saran

Tahapan terakhir adalah pembuatan kesimpulan yang memuat seluruh rangkuman hasil yang diperoleh dan saran untuk penelitian selanjutnya

\section{Perancangan Model Simulasi}

\section{A. Model Konseptual}

Perancangan model simulasi untuk evaluasi model perencanaan persediaan obat pada penelitian ini diselesaikan dengan menggunakan software Microsoft Excel dan Arena ${ }^{\circledR}$. Software Microsoft Excel ini digunakan pada proses inisialisasi yang terdiri dari beberapa langkah yaitu mulai dari pengumpulan data hingga pengolahan data dengan menggunakan tiga metode perencanaan persediaan yang telah dijelaskan sebelumnya. Setelah itu dilakukan perancangan model simulasi dengan Arena ${ }^{\circledR}$ dimana input untuk Arena ${ }^{\circledR}$ ini adalah hasil perhitungan dari Microsoft Excel yang telah diselesaikan sebelumnya. Kemudian output dari Arena $^{\circledR}$ ini akan dibaca kembali oleh Microsoft Excel.

\section{B. Proses Inisialisasi}

Proses inisialisasi ini terdiri dari beberapa langkah sebagai berikut.

1. Pengumpulan data

Data yang dikumpulkan untuk melakukan analisis dan pemilihan metode dalam menentukan kuantitas persediaan obat pada Rumah Sakit X yaitu sebagai berikut: data permintaan obat selama tahun 2017, data jumlah persediaan obat selama tahun 2017, data obat yang mengalami stockout selama tahun 2017 dan biaya-biaya persediaan obat yang berlaku pada saat pengumpulan data.

2. Pengelompokan produk

Pengelompokan produk ini dilakukan berdasarkan analisis $\mathrm{ABC}$ dengan kriteria nilai permintaan dan harga produk. Kriteria pengelompokan obat-obatan berdasarkan kriteria nilai permintaan dapat dilihat pada Tabel 1, sedangkan pengelompokkan produk berdasarkan harga termahal ditampilkan pada Tabel 2. 
Tabel 1. Rekapitulasi pengklasifikasian obat-obatan berdasarkan nilai permintaan

\begin{tabular}{|c|c|cr|c|}
\hline Klasifikasi & $\begin{array}{c}\text { Jumlah } \\
\text { Item }\end{array}$ & $\begin{array}{c}\text { Total Nilai } \\
\text { Permintaan (Rp) }\end{array}$ & $\begin{array}{c}\text { Persentase } \\
\text { Nilai } \\
\text { Permintaan }\end{array}$ \\
\hline A & 85 & Rp & $18,501,134,771.03$ & $79.74 \%$ \\
B & 133 & Rp & $3,377,849,422.81$ & $14.56 \%$ \\
C & 283 & Rp & $1,324,218,474.16$ & $5.71 \%$ \\
\hline Jumlah & $\mathbf{5 0 1}$ & Rp & $\mathbf{2 3 , 2 0 3 , 2 0 2 , 6 6 8 . 0 0}$ & $\mathbf{1 0 0 \%}$ \\
\hline
\end{tabular}

Tabel 2. Rekapitulasi 10 jenis obat termahal

\begin{tabular}{|c|c|c|c|c|c|}
\hline No & $\begin{array}{c}\text { Kode } \\
\text { Produk }\end{array}$ & Nama Obat & Satuan & Ke mas an & Harga Beli \\
\hline 1 & B05008 & Epinephrine $20 \mathrm{mg} / 2 \mathrm{~mL}$ & Cairan Injeksi & Vial & $\mathrm{Rp} \quad 455,290$ \\
\hline 2 & B05004 & Insulin $100 \mathrm{UI} / \mathrm{mL}$ & Larutan & Vial & Rp $\quad 380,270$ \\
\hline 3 & A04009 & Vaksin jerap $5 \mathrm{~mL}$ & Larutan & Vial & $\mathrm{Rp} \quad 376,572$ \\
\hline 4 & A04009 & Fentanyl $100 \mathrm{mcg}$ & Injeksi Infus & Vial & Rp 346,500 \\
\hline 5 & F50002 & Levothyroxine $500 \mathrm{mcg}$ & Inhalasi Aerosol & Vial & $\operatorname{Rp} 343,200$ \\
\hline 6 & B05051 & Tebokan Spesial tss & 30 Tablet & Box & $\mathrm{Rp} \quad 343,090$ \\
\hline 7 & B05051 & Meropros $1 \mathrm{~g}$ Serbuk inj/1 vial @ $1 \mathrm{~g}$ & Serbuk Injeksi & Vial & $\mathrm{Rp} \quad 314,380$ \\
\hline 8 & A05005 & Vaksin polio $50 \mathrm{~mL}$ & Larutan & Vial & Rp $\quad 294,800$ \\
\hline 9 & A05047 & Fluticasone $0,05 \%$ & Serbuk Injeksi & Vial & $\mathrm{Rp} \quad 284,900$ \\
\hline 10 & B05051 & Fluticasone $50 \mathrm{mcg}$ & Injeksi Intravena & Vial & $\mathrm{Rp} \quad 269,500$ \\
\hline
\end{tabular}

3. Perhitungan nilai kebijakan persediaan dan konsekuensi service level dan total cost masingmasing metode

a. Metode EOQ

Jumlah pemesanan optimal pada metode EOQ dapat dihitung dengan persamaan [3]:

$$
\mathrm{EOQ}=\sqrt{\frac{2 \mathrm{CR}}{\mathrm{PF}}}
$$

Nilai total cost dapat dihitung dengan persamaan [3]:

$$
\mathrm{TC}(\mathrm{Q})=\mathrm{PR}+\frac{\mathrm{CR}}{\mathrm{Q}}+\frac{\mathrm{HQ}}{2}
$$

Hasil perhitungan nilai kebijakan persediaan dengan metode EOQ dapat dilihat pada Tabel 3. 
Tabel 3. Perhitungan Nilai Kebijakan Persediaan dengan Metode EOQ

\begin{tabular}{|c|c|c|c|c|c|c|}
\hline $\mathbf{Q}$ & OP & $\mathbf{O S}$ & $\mathbf{O K}$ & TC & ROP & SL \\
\hline 41 & $1,819,33$ & $1,852,733.26$ & Rp 3,125,545.94 & $\operatorname{Rp} \quad 7,174,182.69$ & 31 & $\overline{840}$ \\
\hline & 1,7 & 1,7 & Rp 17, & Rp 21,520 & 32 & $6^{0}$ \\
\hline 50 & 1,6 & 1,70 & Rp 47,' & Rp 51,075 & 34 & \\
\hline & & & p 1 & p 2 & & \\
\hline 68 & Rp 1,433 & p 1,433 & $\operatorname{Rp} 11,0$ & $\operatorname{Rp} 13,921$ & 40 & 70 \\
\hline 37 & p 1,29 & 13 & Rp $\quad 5,276,92$ & $\mathrm{Rp} \quad 7,878$ & 0 & \\
\hline 41 & Rp 1,258 & Rp 1,303 & $\mathrm{Rp}$ & 2,562, & & \\
\hline 44 & $\operatorname{Rp} 1,271$ & Rp 1,272. & $\mathrm{Rp}$ & 2,543, & 23 & 60 \\
\hline 6 & Rp 1,087. & Rp 1,089 & $8,813,750.00$ & Rp 10,989, & 29 & J \\
\hline 45 & $963,253.66$ & 980,1 & $6,588,450.00$ & $\operatorname{Rp} 8,531,8$ & 18 & \\
\hline 3 & 934,0 & 970 , & $\mathrm{Rp}$ & $1,904,2$ & 13 & \\
\hline & $911,497.55$ & $928,699.20$ & $7,720,284.00$ & $9,560,480.75$ & 31 & \\
\hline
\end{tabular}

b. Metode Joint Replenisment

Nilai pemesanan optimal dihitung dengan persamaan [7]:

$$
\mathrm{Qs} *=\sqrt{\frac{2\left(\mathrm{~S}+\sum \mathrm{s}_{\mathrm{i}}\right) \mathrm{A}}{\mathrm{k}}}
$$

Nilai pemesanan optimal per item dihitung dengan persamaan [7]:

$$
Q s_{\mathrm{i}}^{*}=\left(\frac{\mathrm{a}_{\mathrm{i}}}{\mathrm{A}}\right) \mathrm{Qs}^{*}
$$

Kuantitas pemesanan optimal per item dalam satu unit dihitung dengan persamaan [7]:

$$
\text { Qs* }=\frac{\mathrm{Qsi}^{*}}{\mathrm{Ci}}
$$

Interval pemesanan persamaan adalah [7]:

$$
\mathrm{T}=\frac{1}{\mathrm{~N}}=\frac{1}{\frac{\mathrm{A}_{*}}{\mathrm{Q}^{*}}}=\frac{\mathrm{QS}^{*}}{\mathrm{~A}}
$$

Rekapitulasi perhitungan nilai persediaan

\begin{tabular}{|c|c|c|c|c|c|c|c|c|c|c|}
\hline$Q^{*}$ & $\begin{array}{c}\mathbf{T} \\
\text { Hari }\end{array}$ & & OP & & $\mathbf{O S}$ & & $\mathbf{O K}$ & & $\mathbf{T C}$ & SL \\
\hline 13 & 2 & $\mathrm{Rp}$ & $191,263.08$ & $\mathrm{Rp}$ & 58745201 & $\mathrm{Rp}$ & $3,125,545.94$ & 14 & $4,280,832.82$ & $99 \%$ \\
\hline 14 & 2 & $\mathrm{Rp}$ & $182,667.88$ & $\mathrm{Rp}$ & $582,120.00$ & $\mathrm{Rp}$ & 17,948 & $\mathrm{Rp}$ & $19,059,987.88$ & $99 \%$ \\
\hline 15 & 2 & $\mathrm{Rp}$ & $182,778.25$ & $\mathrm{Rp}$ & $512,820.00$ & $\mathrm{Rp}$ & $47,720,750.00$ & $\mathrm{Rp}$ & $48,701,248.25$ & $99 \%$ \\
\hline 11 & 2 & $\mathrm{Rp}$ & 189,9 & $\mathrm{Rp}$ & 452 , & $\mathrm{Rp}$ & 16,81 & $\mathrm{Rp}$ & 17,79 & $99 \%$ \\
\hline 17 & 2 & $\mathrm{Rp}$ & $191,159.20$ & $\mathrm{Rp}$ & $358,492.46$ & $\mathrm{Rp}$ & $11,053,517.64$ & $\mathrm{Rp}$ & $11,778,900.91$ & $99 \%$ \\
\hline 9 & 2 & $\mathrm{Rp}$ & 177,1 & $\mathrm{Rp}$ & 34.00 & $\mathrm{Rp}$ & $5,276,920.00$ & $\mathrm{Rp}$ & 266.31 & $99 \%$ \\
\hline 9 & 2 & $\mathrm{Rp}$ & $191,140.33$ & $\mathrm{Rp}$ & $286,189.20$ & $\mathrm{Rp}$ & - & $\mathrm{Rp}$ & $742,319.53$ & $99 \%$ \\
\hline 10 & 2 & $\mathrm{Rp}$ & $186,486.54$ & $\mathrm{Rp}$ & $289,185.60$ & $\mathrm{Rp}$ & - & $\mathrm{Rp}$ & $716,660.14$ & $99 \%$ \\
\hline 13 & 2 & $\mathrm{Rp}$ & $183,956.28$ & $\mathrm{Rp}$ & $214,500.00$ & $\mathrm{Rp}$ & $8,813,750.00$ & $\mathrm{Rp}$ & $9,349,706.28$ & $99 \%$ \\
\hline 8 & 2 & $\mathrm{Rp}$ & $180,610.06$ & $\mathrm{Rp}$ & $174,240.00$ & $\mathrm{Rp}$ & $6,588,450.00$ & $\mathrm{Rp}$ & $7,124,800.06$ & $99 \%$ \\
\hline 6 & 2 & $\mathrm{Rp}$ & $181,627.03$ & $\mathrm{Rp}$ & $166,320.00$ & $\mathrm{Rp}$ & - & $\mathrm{Rp}$ & $578,947.03$ & $99 \%$ \\
\hline 13 & 2 & $\mathrm{Rp}$ & $191,648.20$ & $\mathrm{Rp}$ & $147,232.80$ & $\mathrm{Rp}$ & $7,720,284.00$ & $\mathrm{Rp}$ & $8,153,545.00$ & $99 \%$ \\
\hline
\end{tabular}
berdasarkan metode Joint Replenishment dapat dilihat pada Tabel 4 .

Tabel 4. Rekapitulasi Nilai Kebijakan Persediaan dengan Metode JR

c. Metode Sistem (Q,r)

$\mathrm{Q}_{1}$ dihitung menggunakan persamaan [8]:

$$
\alpha=\frac{\mathrm{hQ}}{\text { So.D }} ; \mathrm{r}=\mathrm{Z}_{\alpha} \cdot \sigma_{\mathrm{L}}+\mu
$$

$$
\mathrm{Q}_{1}=\sqrt{\frac{2 \mathrm{DB}}{\mathrm{h}}}
$$

Nilai dari $\mathrm{r}_{1}$ dihitung dengan memasukkan Q1 pada persamaan [8]:

Nilai $M\left(r_{1}\right)$ dihitung, dengan memasukkan nilai $r_{1}$ ke persamaan [8]:

$$
M\left(r_{i}\right)=\sigma_{L} f\left(\frac{r-\mu}{\sigma_{L}}\right)+\sigma_{L}\left(\frac{\mu-r}{\sigma_{L}}\right)\left(\frac{r-\mu}{\sigma_{L}}\right)
$$


Gunakan $\mathrm{M}\left(\mathrm{r}_{1}\right)$ ini untuk mendapatkan $\mathrm{Q}_{2}$ dalam persamaan [8]:

$$
\mathrm{Q} *=\sqrt{\frac{2 \mathrm{D}_{\mathrm{i}}\left(\mathrm{B}_{\mathrm{i}}+\mathrm{So}_{\mathrm{i}} \mathrm{M}_{\mathrm{i}}\right.}{\mathrm{h}_{\mathrm{i}}}}
$$

Nilai $r_{2}$ dihitung seperti pada langkah kedua. Cara ini dilanjutkan sampai nilai $\mathrm{Q}_{i}$ dan $\mathrm{r}_{\mathrm{i}}$ menuju satu harga tertentu yang tidak berubah artinya menuju ke konvergen. Sehingga didapatkan nilai $\mathrm{Q}^{*}$ dan $\mathrm{r}^{*}$ optimal. Rekapitulasi perhitungan nilai persediaan berdasarkan metode Sistem (Q,r) dapat dilihat pada Tabel 5 .

Langkah - langkah perhitungan nilai service level:
1. Menghitung besarnya nilai permintaan selama leadtime (M). Dimana leadtime pada penelitian ini konstan yaitu 3 hari.

2. Setelah dihitung permintaan selama leadtime untuk satu tahun maka dihitung nilai probabilitas dari masing-masing nilai permintaan untuk setiap obatnya $[\mathrm{P}(\mathrm{M})]$.

3. Kemudian dihitung nilai ekspektasi nilai permintaan selama leadtime besar dari nilai ROP $[E(M>r)]$

Setelah didapatkan nilai $\mathrm{E}(\mathrm{M}>\mathrm{r})$ maka dihitung nilai service level dengan persamaan $\mathrm{SL}_{\mathrm{u}}=1-\frac{E(M>r)}{\mathrm{Q}}$. Perbandingan total cost dan service level yang didapatkan dari ketiga metode dapat dilihat pada Tabel 6.

Tabel 5. Rekapitulasi Nilai Kebijakan Persediaan dengan Metode Sistem (Q,r)

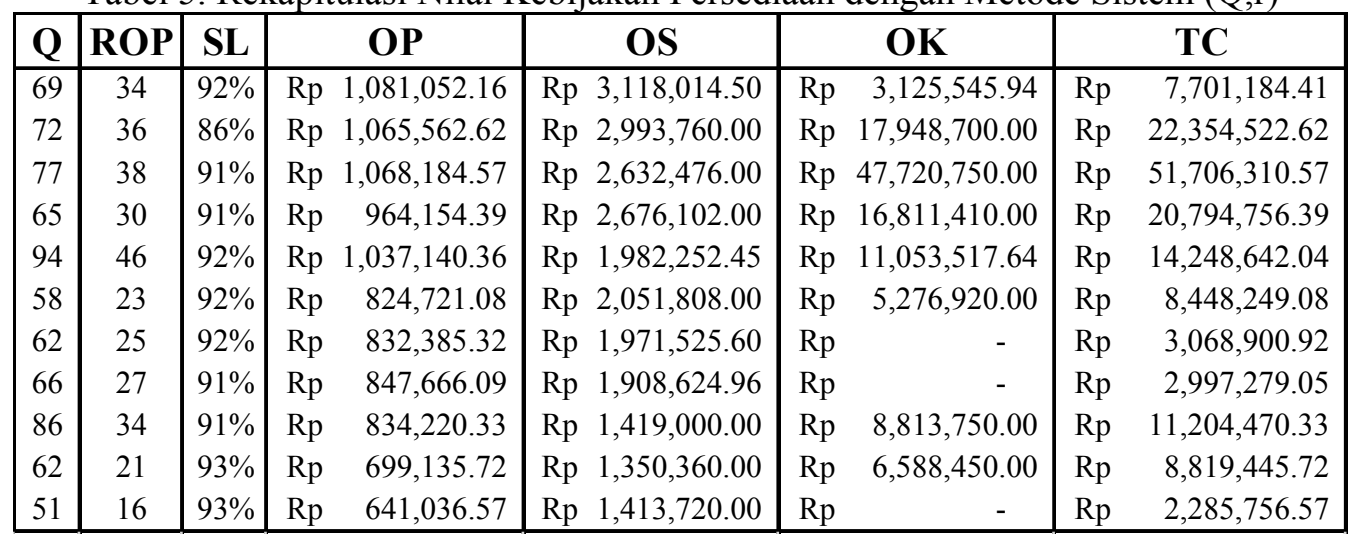

Tabel 6. Perbandingan Hasil Perhitungan Ketiga Metode

\begin{tabular}{|c|c|cc|c|}
\hline \multirow{2}{*}{ No } & \multicolumn{3}{|c|}{ Pemilihan Metode } \\
\cline { 2 - 5 } & Metode & \multicolumn{2}{|c|}{ Total Cost } & SL \\
\hline 1 & EOQ & $\operatorname{Rp}$ & $367,960,003.39$ & $92 \%$ \\
2 & JR & $R p$ & $281,993,843.00$ & $98 \%$ \\
3 & Sistem Q,r & $R p$ & $381,678,706.97$ & $95 \%$ \\
\hline
\end{tabular}

Pada Tabel 6 dapat dilihat bahwa total cost terendah dan nilai service level tertinggi didapatkan pada metode Joint Replenishment sehingga dapat diambil kesimpulan bahwa metode Joint Replenishment ini bisa digunakan untuk meningkatkan service level dan total cost dari apotek Rumah Sakit X.

\section{Model Simulasi}

Logika model simulasi untuk metode EOQ dan Sistem (Q,r) secara keseluruhan sama. Hanya saja yang membedakan kedua metode ini pada input nilai pemesanan optimal dan nilai dari reorder point untuk masing-masing obat. Sedangkan model simulasi untuk metode Joint Replenistment memiliki sedikit perbedaan dengan kedua metode EOQ dan Sistem (Q,r). Perbedaannya terdapat pada logika pemesanan kembali. Jika pada metode EOQ dan Sistem (Q,r) pemesanan obat dipengaruhi oleh titik reorder point, maka pada metode Joint Replenishment pemesanan obat dipengaruhi oleh interval waktu yang tetap tanpa adanya reorder point. Untuk lebih jelasnya model simulasi untuk metode EOQ, Joint Replenishment, dan Sistem (Q,r) dapat dilihat pada Gambar 1 sampai Gambar 3. 

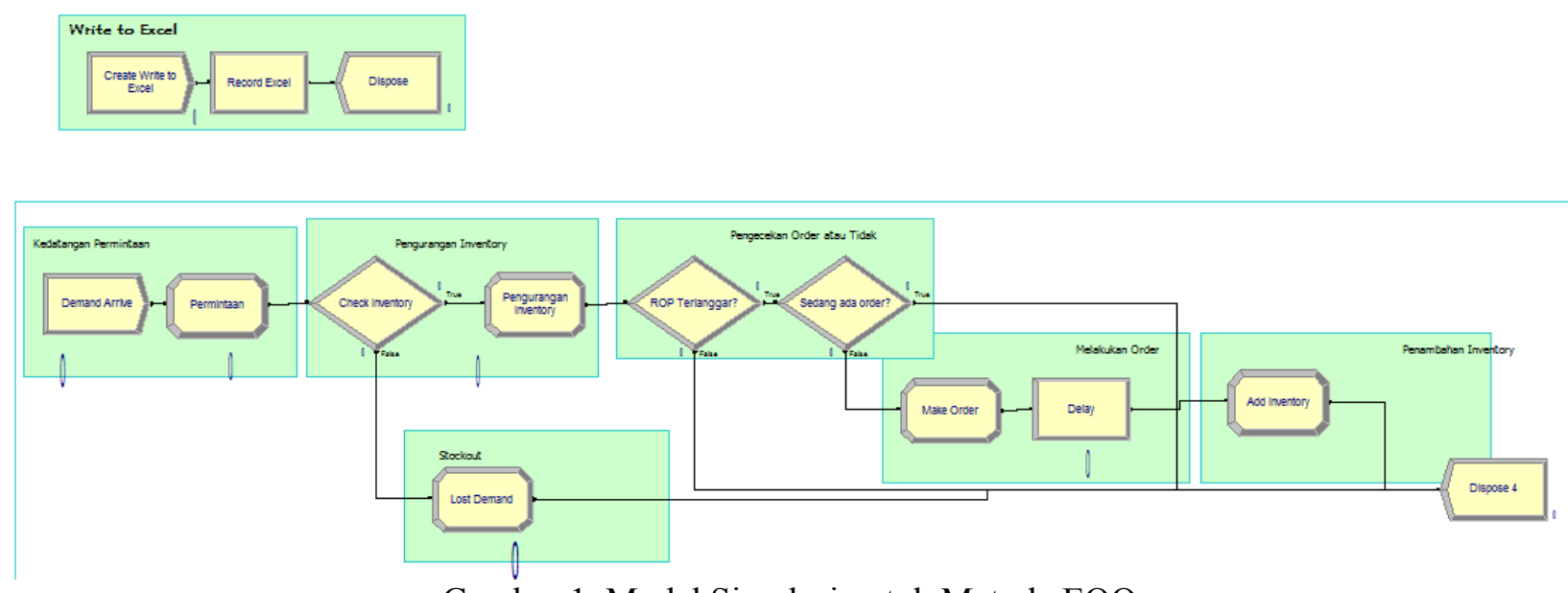

Gambar 1. Model Simulasi untuk Metode EOQ

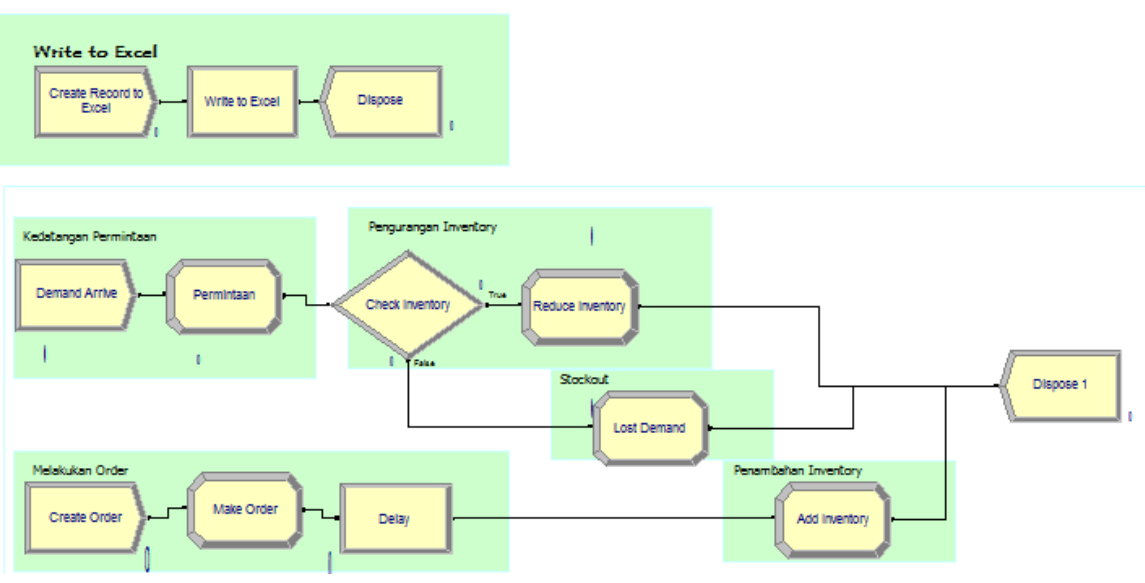

Gambar 2. Model Simulasi untuk Metode Joint Replenishment
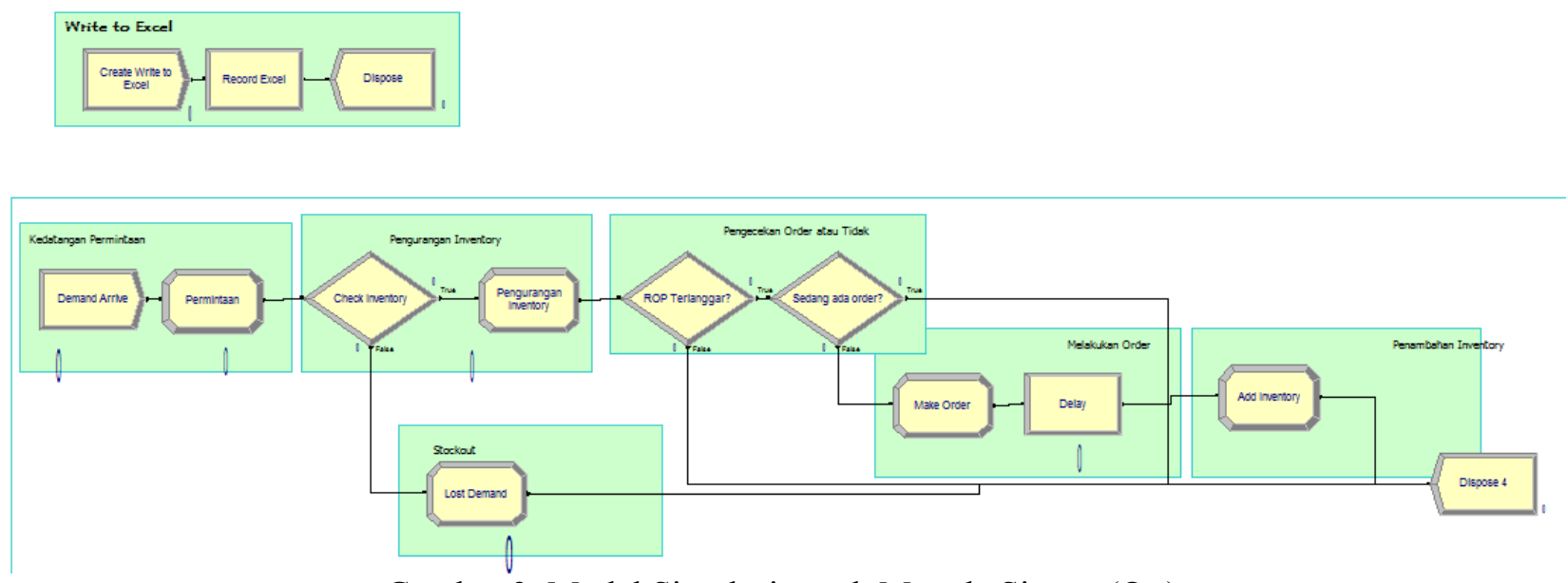

Gambar 3. Model Simulasi untuk Metode Sistem (Q,r)

Proses yang terjadi dalam model simulasi ini dibagi atas beberapa event. Proses tersebut terdiri dari sebagai berikut.

1. Model logika untuk kedatangan permintaan obat
Modul yang digunakan untuk memodelkan proses ini adalah Create - Assign seperti pada Gambar 4. 
a.
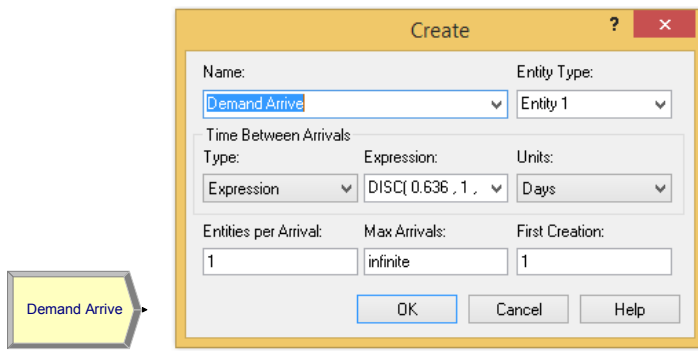

b.

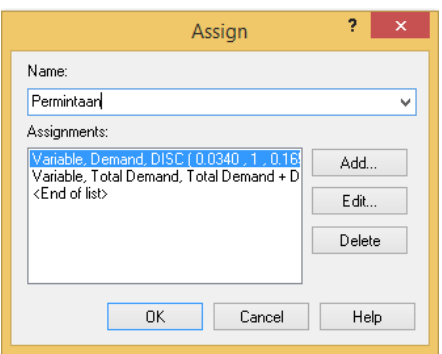

Gambar 4. Logika kedatangan permintaan obat

2. Model logika untuk pengeluaran obat

Proses pengeluaran obat dilakukan jika ada permintaan terhadap obat tersebut. Jika ada permintaan maka terdapat proses pemilihan dengan menggunakan modul Decide, dimana ada dua pilihan yaitu sebagai berikut.

a. Jika permintaan obat $\leq$ persediaan maka obat yang diminta akan dikeluarkan sebanyak permintaan.

b. Jika permintaan obat $>$ persediaan maka obat yang diminta tidak akan dikeluarkan dan dilakukan perhitungan jumlah stockout. Untuk proses stockout ini dapat dijelaskan pada bagian stockout.

Modul Assign akan mengurangi persediaan berdasarkan jumlah yang diminta. Proses pengeluaran obat dapat dilihat pada Gambar 5 dan Gambar 6.

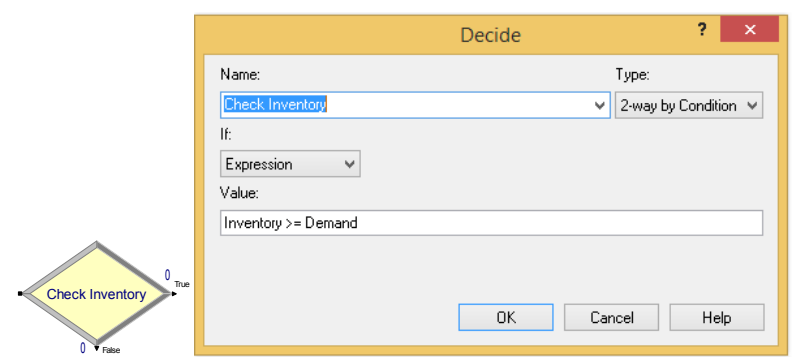

Gambar 5. Logika pengecekan inventory

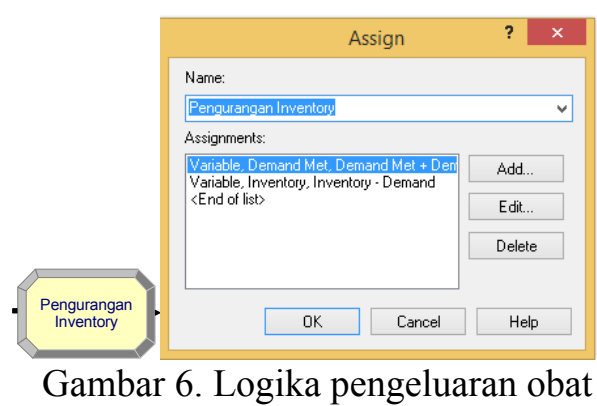

Gambar 6 menjelaskan bahwa proses pengeluaran obat dimulai dari modul Decide dimana modul Decide akan melihat posisi inventory dari obat. Jika permintaan obat lebih kecil dari inventory maka obat akan dikeluarkan melalui modul Assign.

\section{Model logika untuk Stockout}

Sebagaimana yang telah dijelaskan pada bagian sebelumnya, proses stockout terjadi jika permintaan obat $>$ persediaan sehingga obat yang diminta tidak dikeluarkan dan dilakukan perhitungan jumlah stockout dengan model sebagai berikut dapat dilihat pada Gambar 7.

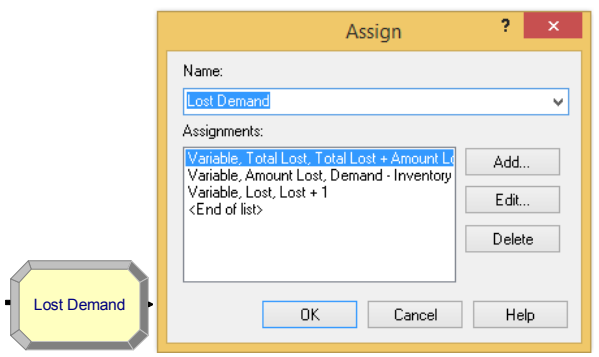

Gambar 7. Logika Stockout

Perhitungan nilai stockout atau lost demand yaitu besarnya permintaan dikurangi dengan inventory yang ada pada saat permintaan datang. Hal ini dikarenakan perhitungan jumlah permintaan dalam sistem simulasi ini dilakukan per hari sedangkan permintaan obat dalam satu hari tidak hanya datang dari satu orang konsumen saja melainkan bisa dari beberapa konsumen yang jumlahnya tidak terbatas. Proses stockout ini dikeluarkan melalui modul Assign.

4. Model logika untuk pemesanan kembali Proses pemesanan kembali dilakukan ketika posisi Inventory $<=$ Reorder Point. Langkah pertama yang dilakukan yaitu mengecek posisi persediaan dengan menggunakan modul Decide. Jika persediaan $<=$ ROP maka dilakukan order dengan modul Assign. Model 
logika pemesanan kembali dapat dilihat pada model Gambar 8 sampai Gambar 12.

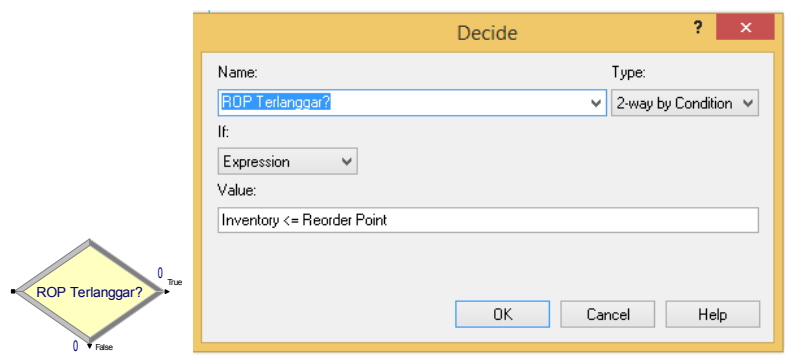

Gambar 8. Logika pengecekan ROP terlanggar/tidak

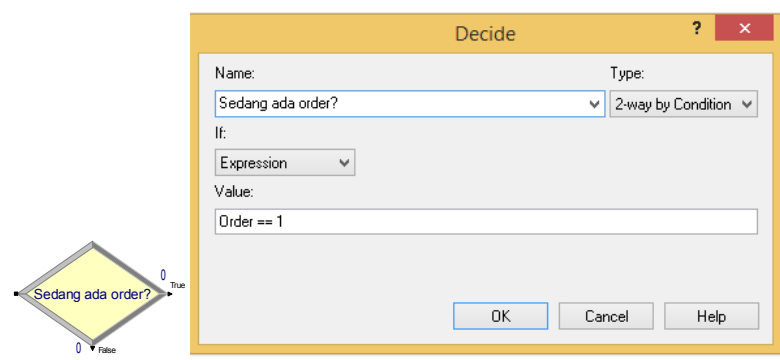

Gambar 9. Logika pengecekan sedang ada order/tidak

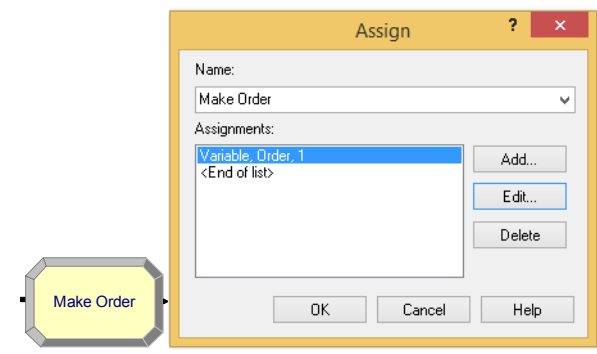

Gambar 10. Logika Order

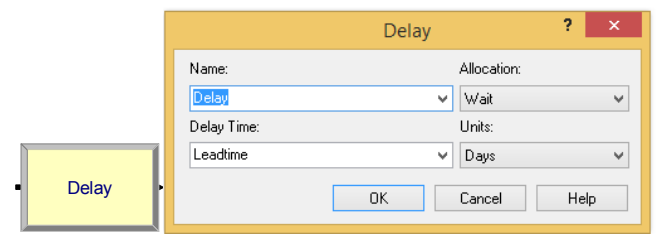

Gambar 11. Logika Delay

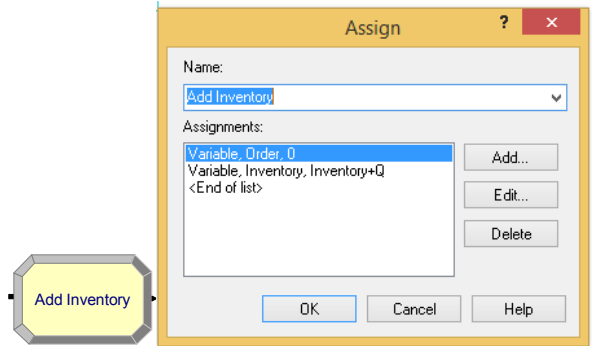

Gambar 12. Logika penambahan Inventory

Gambar 12 menjelaskan proses pemesanan kembali untuk persediaan obat yang berada dibawah titik reorder point dengan menggunakan modul Decide. Pemesanan kembali dilakukan dengan modul Assign. Setalah dilakukan pemesanan kembali, maka pesanan akan sampai 3 hari setelah pemesanan. Proses menunggu ini dilakukan pada modul Delay. Jika pesanan sudah sampai maka akan dilakukan penambahan inventory sebanyak pemesanan optimal dan ini dilakukan oleh modul Assign. Setelah semua proses dilakukan maka akan diakhiri dengan modul Dispose.

5. Model logika untuk me-record hasil simulasi ke Microsoft Excel

Proses ini merupakan hasil dari Arena ${ }^{\circledR}$ yang akan disimpan pada Microsoft Excel. Microsoft Excel akan menyimpan data sesuai dengan apa yang kita inginkan pada Arena ${ }^{\circledR}$. Salah satu contoh data yang akan disimpan pada Microsoft Excel yaitu data waktu antar kedatangan permintaan obat dan data permintaan obat setiap harinya. Modul yang digunakan untuk proses ini yaitu modul ReadWrite yang ada pada Arena $^{\circledR}$. Proses penggunaan modul ReadWrite dapat dilihat pada model Gambar 13.

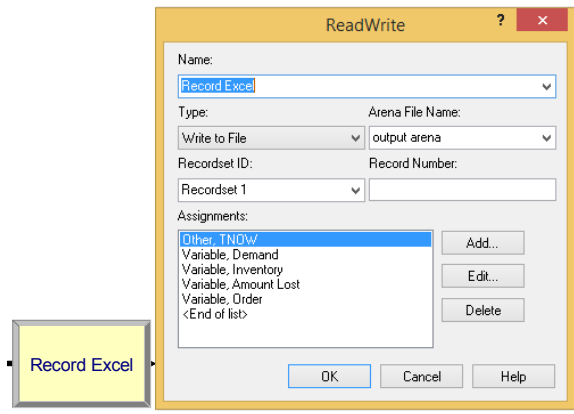

Gambar 13. Proses ReadWrite

Gambar 13 menjelaskan bahwa Microsoft Excel akan menyimpan data waktu antar kedatangan permintaan, jumlah permintaan, posisi inventory, jumlah stockout untuk setiap harinya serta kapan akan dilakukan pemesanan kembali.

\section{Verifikasi}

Verifikasi merupakan langkah untuk mengetahui apakah model simulasi komputer yang telah dibangun dapat berjalan sesuai dengan spesifikasi model yang diinginkan.

Proses verifikasi dilakukan dengan cara sebagai berikut:

1. Melakukan debugging terhadap program simulasi yang telah dibuat untuk mendeteksi kesalahan-kesalahan yang terdapat dalam konfigurasi program. Proses ini pada software Arena ${ }^{\circledR}$ dilakukan dengan mengaktifkan tombol 
check (v). Jika terdapat kesalahan dalam konfigurasi program, maka secara otomatis akan keluar peringatan yang berisi laporan kesalahan (error massege) dari beberapa konfigurasi program dan selanjutnya harus dilakukan perbaikan terhadap konfigurasi program.

2. Verifikasi selanjutnya dilakukan terhadap model yang telah dibuat dengan input nilai konstan terhadap nilai distribusi sebenarnya yaitu nilai distribusi antar kedatangan dan distribusi permintaan untuk masing-masing obat. Setelah dilakukan input nilai konstan terhadap model simulasi, ternyata nilai yang dikeluarkan oleh model sama dengan nilai kontan yang diberikan. Dengan kata lain, model simulasi yang telah dibangun sudah terverifikasi.

3. Verifikasi juga dapat dilakukan dengan mengamati animasi selama program berjalan. Melalui animasi dapat dilihat bagaimana mekanisme dari model selama periode waktu simulasi. Di sini dapat diketahui apakah program sudah dapat berjalan dengan logika dan spesifikasi yang diinginkan. Animasi dapat berupa tampilan grafik atau angka-angka yang menunjukkan nilai suatu variabel selama periode waktu tertentu.

\section{E. Validasi Model}

Ada beberapa pendekatan yang digunakan dalam melakukan validasi terhadap model simulasi yaitu sebagai berikut.

1. Model kotak hitam (Black Box Validation)

Validasi ini dilakukan dengan cara membandingkan hasil simulasi dengan hasil peformansi sistem nyata. Nilai yang menjadi parameter perbandingan adalah frekuensi permintaan dan jumlah permintaan untuk masing-masing obat selama satu tahun. Perbandingan output model simulasi dengan hasil peformansi sistem nyata dapat dilihat pada Tabel 7.

Tabel 7 Perbandingan Hasil Sistem Nyata dengan Simulasi

\begin{tabular}{|c|c|c|c|c|}
\hline \multirow{2}{*}{ No } & \multicolumn{2}{|c|}{ Fre kue nsi Permintaan } & \multicolumn{2}{|c|}{ Total Permintaan } \\
\cline { 2 - 5 } & $\begin{array}{c}\text { Sistem } \\
\text { Nyata }\end{array}$ & Simulasi & $\begin{array}{c}\text { Sis tem } \\
\text { Nyata }\end{array}$ & Simulasi \\
\hline 1 & 206 & 209 & 3730 & 4000 \\
2 & 193 & 176 & 3836 & 3881 \\
3 & 232 & 241 & 4114 & 4089 \\
4 & 192 & 191 & 3134 & 3647 \\
5 & 212 & 218 & 4872 & 5487 \\
6 & 203 & 218 & 2391 & 2349 \\
7 & 154 & 141 & 2580 & 2565 \\
\hline
\end{tabular}

Validasi tahap ini juga dilakukan dengan uji $\mathrm{T}$ untuk membandingkan nilai rataan antara output simulasi dengan sistem nyata. Pada uji T ini asumsi yang digunakan adalah bahwa variansi kedua sampel sama. Hipotesa awal yang diuji adalah bahwa kedua populasi memiliki nilai rataan yang sama sedangkan hipotesa tandingannya adalah kedua populasi mempunyai nilai rataan yang tidak sama.

$$
\begin{aligned}
& \text { Ho : } \mu_{1}=\mu_{2} \\
& \text { Ho : } \mu_{1} \neq \mu_{2}
\end{aligned}
$$

Proses validasi model simulasi dilakukan pada data ouput untuk ke 85 jenis obat yang diteliti. Pengujian dilakukan dengan menggunakan Pair-sample T Test yang terdapat pada software SPSS. Hasil pengujian dengan menggunakan uji $\mathrm{T}$ dapat dilihat pada Gambar 14 dan Gambar 15.

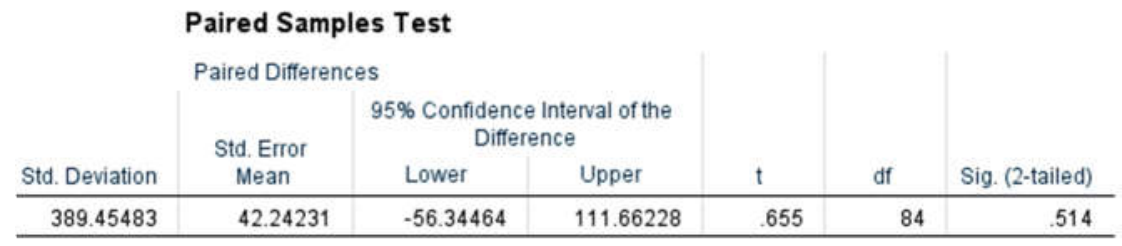

Gambar 14. Hasil Pair-sample T Test untuk Validasi Frekuensi Permintaan 


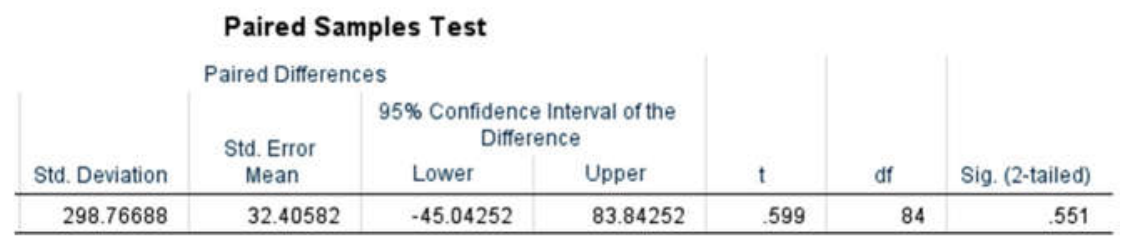

Gambar 15. Hasil Pair-sample T Test untuk Validasi Jumlah Permintaan

Hipotesa nol diterima jika nilai T hitung kurang dari atau sama dengan nilai $\mathrm{T}$ tabel, atau nilai significance level nya lebih dari nilai alpha. Dari Gambar 14 dan Gambar 15 di atas dapat diketahui bahwa nilai significance level lebih besar dari alpha $(0,05)$. Sehingga dapat diambil kesimpulan bahwa hipotesa nol diterima dan dinyatakan bahwa tidak ada perbedaan rataan antara hasil simulasi dengan hasil observasi sistem nyata. Kesimpulan ini menunjukkan bahwa model simulasi valid dan dapat digunakan sebagai representasi sistem dalam melakukan analisa peformansi sistem.

\section{Model Kotak Putih (White Box Validation)}

Metode ini dilakukan untuk memastikan bahwa detail-detail yang terdapat dalam model simulasi sama dengan detail-detail yang terdapat dalam sistem. Beberapa aspek yang perlu dipertimbangkan dalam White Box Validation adalah sebagai berikut:

a. Distribusi Input

Input yang digunakan dalam model ini terdiri dari data deterministik dan stokastik. Penentuan nilai distribusi digunakan untuk data yang bersifat stokastik yang menggambarkan sifat ketidakpastian data dari sistem tersebut. Data input yang bersifat stokastik tersebut antara lain data jumlah permintaan dan waktu antar kedatangan obat per hari untuk masing-masing jenis obat. Sebagaimana yang telah dijelaskan sebelumnya bahwa untuk distribusi kedua data stokastik tersebut digunakan distribusi diskrit.

b. Logika Statis

Aturan yang berlaku untuk logika statis dalam simulasi diskrit adalah If (Kondisi) Then (Aksi). Pada model simulasi sistem persediaan obat di apotek Rumah Sakit X ini, logika statis yang digunakan adalah pada event pengeluaran obat yang disebabkan karena adanya permintaan. Dimana terdapat 2 kondisi yaitu sebagai berikut.

1) Jika permintaan obat $\leq$ persediaan maka obat akan dikeluarkan sebanyak permintaan

2) Jika permintaan obat $>$ persediaan maka obat yang diminta akan mengalami stockout

c. Logika Dinamis

Kemampuan model simulasi untuk dapat menirukan prilaku dinamis sistem nyatanya secara keseluruhan menunjukkan bahwa model dapat mewakili sistem nyata. Beberapa cara yang digunakan untuk melihat perubahan variabel dan state yang terjadi selama simulasi berjalan adalah dengan menggunakan tabel, grafik, atau ikon-ikon tertentu pada model. Logika dinamis untuk model sistem persediaan obat ini dapat dilihat pada tampilan animasi selama running simulasi. Dari tampilan animasi pada model ini dapat dilihat pergerakan entity melewati sistem dari waktu ke waktu. Selain itu, pada tampilan grafik dapat dilihat perubahan nilai peformansi sistem selama simulasi berjalan. Berdasarkan logika dinamis, model ini juga sudah dapat mewakili sistem nyata.

\section{F. Evaluasi Ketiga Metode Persediaan dengan} Simulasi

Evaluasi ini dilakukan untuk mendapatkan metode terbaik dari ketiga metode persediaan yang telah dibahas sebelumnya. Pemilihan metode terbaik disini berdasarkan nilai service level tertinggi dan total cost terendah. Hasil dari evaluasi untuk ketiga metode persediaan dapat dilihat pada Tabel 8. 
Tabel 8 Hasil Evaluasi dengan Simulasi

\begin{tabular}{|c|c|c|c|c|}
\hline \multicolumn{5}{|c|}{ Evaluasi } \\
\hline & & EOQ & JR & Qr \\
\hline Stockout & & 16502 & 12996 & 13719 \\
\hline \multirow{3}{*}{ Service } & Max & $100 \%$ & $100 \%$ & $100 \%$ \\
\cline { 2 - 3 } Level & Rata-rata & $93 \%$ & $96 \%$ & $95 \%$ \\
\cline { 2 - 3 } & Min & $82 \%$ & $82 \%$ & $80 \%$ \\
\hline Total cost & & $\mathrm{Rp} 295,515,866.79$ & $\mathrm{Rp} 141,035,712.50$ & $\mathrm{Rp} 250,276,707.01$ \\
\hline
\end{tabular}

Tabel 8 menunjukan hasil evaluasi dari 85 obat untuk masing-masing metode dengan simulasi. Nilai stockout dan total cost merupakan hasil dari penjumlahan untuk 85 obat, sedangkan nilai service level merupakan nilai rata-rata dari 85 obat yang diteliti. Tabel ini juga menjelaskan bahwa metode terbaik untuk perencanaan kuantitas persediaan obat di apotek Rumah Sakit X terdapat pada metode Joint Replenishment dimana sistem yang menggunakan metode Joint Replenishment memiliki jumlah obat yang stockout paling kecil sehingga nilai service levelnya tertinggi dan total cost-nya terendah dari ketiga metode diatas.

\section{G. Analisis Pemilihan Metode}

Pada Tabel 8 dapat dilihat bahwa metode JR memiliki jumlah obat yang stockout paling kecil sehingga nilai service levelnya tertinggi diantara ketiga metode tersebut dan total cost-nya terendah dari ketiga metode diatas. Hasil yang diberikan dengan menggunakan perhitungan Microsoft Excel dan juga menggunakan simulasi tetap sama sehingga dapat diambil kesimpulan bahwa metode yang sebaiknya digunakan untuk menentukan kuantitas persediaan obat pada apotek Rumah Sakit $\mathrm{X}$ yaitu menggunakan metode Joint Replenishment.

\section{KESIMPULAN}

Kesimpulan yang diperoleh dari penelitian ini adalah sebagai berikut:

Berdasarkan hasil perhitungan kebijakan persediaan dan konsekuensi nilai service level dan total cost didapatkan bahwa nilai total cost untuk metode EOQ menghasilkan nilai sebesar $R p$ 367.960.003,39 dan service level 92\%, metode Joint Replenisment menghasilkan nilai total cost $R p$ 281.993.843,00 dan service level 98\%, dan metode Sistem (Q,r) menghasilkan total cost $\mathrm{Rp}$ 381.678.706,97 dan service level 95\%. Hasil dari analisis sensitivitas berdasarkan pendekatan matematis juga menunjukkan bahwa metode terpilih yang memiliki nilai service level tertinggi dan total cost terendah adalah metode Joint Replenishment.

Berdasarkan hasil evaluasi dengan pendekatan simulasi menunjukkan bahwa metode Joint Replenishment (JR) memiliki total cost terendah dan service level tertinggi yaitu sebesar $\mathrm{Rp}$ 141.035.712,50 dan 96\% sedangkan untuk metode EOQ nilai total cost $\mathrm{Rp} 295.515 .866,79$ dan service level sebesar 93\%, untuk metode Sistem (Q,r) nilai total cost $\mathrm{Rp} 250.276 .707,01$ dan service level sebesar 95\%. Hasil analisis sensitivitas pada pendekatan simulasi ini juga menunjukkan bahwa metode terpilih adalah metode Joint Replenishment.

\section{DAfTAR PUSTAKa}

[1] Bahagia, N. (2006). Sistem Inventori. Bandung: ITB

[2] Rangkuti, F. (2007). Manajemen Persediaan: Aplikasi di Bidang Bisnis. Jakarta: PT. Raja Grafindo.

[3] Tersine, R. J. (1994). Principles of Inventory and Materials Management, $4^{\text {th }}$ ed. New Jersey: Prentice Hall.

[4] Jonrinaldi, Rahman, T., Henmaidi, Wirdianto, E. \& Zhang, D. Z. (2018) A Multiple Items EPQ/EOQ Model for a Vendor and Multiple Buyers System with Considering Continuous and Discrete Demand Simultaneously. IOP Conference Series: Materials Science and Engineering, 319012037.

[5] Santosa, B. (2017). Penentuan Kebijakan Persediaan Obat Menggunakan Metode Joint Replenishment Untuk Meningkatkan Service Level Pada Depot Farmasi Rumah 
Sakit XYZ Bandung. Jurnal Program Studi

Teknik Industri Fakultas Rekayasa Industri. Universitas Telkom. Vol (4) No. 1.

[6] Satria, A. (2013). Penerapan Metode Economic Order Quantity (EOQ) Probabilistik Menggunakan Model pada Pengendalian dan Persediaan Obat Antinyeri Mefinal 500mg. Jurnal Jurusan Teknik Industri Fakultas Teknik Universitas Brawijaya. Vol (4) No. 1.

[7] Fogarty, D. W. BlackStone J. H. Jr. and Hoffman T. R.. (1991). Production and Inventory Management. South-Western Publishing Co, Cincinati, Ohio.

[8] Ernawati, Y. dan Sunarsih. (2008). Sistem Pengendalian Persediaan Model Probabilistik Dengan "Back Order Policy". Jurnal Ilmiah Fakultas MIPA UNDIP. Vol (11) No. 2.

\section{NOMENKLATUR}

A : nilai permintaan tahunan seluruh item

$\mathrm{Cu}$ : biaya kekurangan persediaan $(\mathrm{Rp})$

D : permintaan pertahun (unit)

F : fraksi biaya penyimpanan per tahun (\%)

$\mathrm{H}$ : biaya penyimpanan per unit per tahun

L : Leadtime

M : Permintaan selama leadtime

$\mathrm{N}$ : jumlah kekurangan produk

$\mathrm{P}$ : biaya pembelian per unit (Rp/unit)

Q : lot size or order quantity in units

$\mathrm{r}$ : Reorder Point/Titik pemesanan Kembali

$\mathrm{s}$ : biaya pemesanan per pesanan
SL : Service Level

$\mathrm{T}$ : interval pemesanan (tahun)

TC : total biaya persediaan tahunan $(\mathrm{Rp})$

Qs* : nilai pesanan optimal dalam satuan uang

QSi* : nilai pesanan optimal per item dalam satuan uang

Qs*: kuantitas pemesanan optimal per item dalam unit

\section{Biodata Penulis}

Eri Wirdianto memperoleh gelar Sarjana Teknik dari Jurusan Teknik Industri, Universitas Sumatera Utara, dan Master of Science dari University of Bradford, UK. Ia bekerja sebagai dosen di Jurusan Teknik Industri Universitas Andalas sejak 1998 sampai sekarang. Bidang penelitiannya adalah simulasi, riset operasi, statistika, dan sistem distribusi dan transportasi dalam lingkup perancangan dan optimasi sistem industri.

Meiyola Syaflinda menyelesaikan pendidikan sarjana di Jurusan Teknik Industri Universitas Andalas. Ia adalah asisten di Laboratorium Perancangan dan Optimasi Sistem Industri, Jurusan Teknik Industri, Universitas Andalas dari tahun $2016-2018$.

Milana memperoleh gelar Sarjana Teknik dari Jurusan Teknik Industri, Universitas Andalas. Gelar MSc dan PhD diperolehnya dari University of Bradford, UK. Ia bekerja sebagai dosen di Jurusan Teknik Otomotif Universitas Negeri Padang sejak 2008 sampai sekarang. Bidang penelitiannya adalah manajemen industri, knowledge management, dan Knowledge-Based/Expert System dalam lingkup optimasi sistem industri. 
